\title{
A neurological bias in the history of hysteria: from the womb to the nervous system and Charcot
}

\author{
Um viés neurológico na história da histeria: desde o útero até o sistema nervoso e Charcot \\ Marleide da Mota Gomes ${ }^{1}$, Eliasz Engelhardt ${ }^{2,3}$
}

\begin{abstract}
Hysteria conceptions, from ancient Egypt until the $19^{\text {th }}$ century Parisian hospital based studies, are presented from gynaecological and demonological theories to neurological ones. The hysteria protean behavioral disorders based on nervous origin was proposed at the beginning, mainly in Great Britain, by the "enlightenment nerve doctors". The following personages are highlighted: Galen, William, Sydenham, Cullen, Briquet, and Charcot with his School. Charcot who had hysteria and hypnotism probably as his most important long term work, developed his conceptions, initially, based on the same methodology he applied to studies of other neurological disorder. Some of his associates followed him in his hysteria theories, mainly Paul Richer and Gilles de La Tourette who produced, with the master's support, expressive books on Salpêtrière School view on hysteria.
\end{abstract}

Keywords: hysteria, brain, epilepsy, enlightenment, positivism.

\section{RESUMO}

As concepções da histeria, desde o antigo Egito até os estudos baseados nos hospitais parisienses do século 19 são apresentados, a partir de teorias ginecológicas e demonológicas até às neurológicos. A ideia dos transtornos comportamentais multiformes com base na origem nervosa foi proposta no início, principalmente na Grã-Bretanha, pelos "médicos dos nervos do iluminismo". Os seguintes personagens se destacam: Galeno, William, Sydenham, Cullen, Briquet e Charcot com a sua escola. Charcot tinha a histeria e hipnose provavelmente como o seu trabalho mais importante a longo prazo. Ele desenvolveu suas concepções inicialmente com base na mesma metodologia aplicada a estudos sobre outros transtornos neurológicos. Alguns de seus associados seguiram-no em suas teorias, principalmente Paul Richer e Gilles de La Tourette, que produziram, com o apoio do mestre, livros significativos da Escola da Salpêtrière sobre a histeria.

Palavras-chave: histeria, cérebro, epilepsia, iluminismo, positivismo.

"Hysteria" was a leitmotif of Charcot's School, and the history of hysteria and its proteiform symptoms, express the unequal evolution of medicine itself, from beliefs and prejudices until rational essays. This paper presents issues of this pursuit based on a neurological point of view.

\section{HISTORICAL MILESTONES}

The term hysteria comes from the Greek hystera (womb, uterus), and from this emerged the "gynecological" explanation for mood and behavioral abnormalities linked to an ample range of dysfunctions, including psychiatric and neurological ones, that endured for more than two thousand years ${ }^{1}$.

Beginning in ancient Egypt and Greece, the idea of a womb wandering throughout the body, as the cause of hysteria, was in vogue ${ }^{1}$. The charge was credited to semen or blood upholding in the uterus, given that the humors could decay and the resulting distended uterus would be injured by toxic products or by pressure ${ }^{2}$. However, Claudius Galenus [Galen] (129-199/217), considered that this nomadism was unrealistic. Galen's views were held until the end of

\footnotetext{
IInstituto de Neurologia Deolindo Couto, Faculdade de Medicina, Universidade Federal do Rio de Janeiro, Rio de Janeiro RJ, Brazil;

${ }^{2}$ Unidade de Neurologia Cognitiva e Comportamental, Instituto de Neurologia, Universidade Federal do Rio de Janeiro, Rio de Janeiro RJ, Brazil;

${ }^{3}$ Instituto de Psiquiatria, Universidade Federal do Rio de Janeiro, Rio de Janeiro RJ, Brazil.

Correspondence: Marleide da Mota Gomes; Instituto de Neurologia Deolindo Couto, Universidade Federal do Rio de Janeiro; Av. Venceslau Braz, 95; 22290-140 Rio de Janeiro RJ, Brasil; E-mail: mmotagomes@acd.ufrj.br

Conflict of interest: There is no conflict of interest to declare.

Received 23 March 2014; Received in final form 18 July 2014; Accepted 06 August 2014.
} 
the Humor Theory: the disease was caused by the humoral imbalance of blood, phlegm, yellow bile, and black bile. During the Middle Ages hysteria was supposed to be due to diabolical possession and witchcraft. Edward Jorden (1603) regarded the women accused of witchcraft as having a medical condition called "suffocation of the mother" (mother as the uterus). He used the ancient doctrine of "sympathy" to suggest that the womb could affect organs such as the brain, heart and liver ${ }^{1,3}$. The doctrine of sympathy was the earliest attempt to explain "action at distance" of humors or vapors. The nervous system, came to be acknowledged as the main mediator of the "action at distance", by the end of the $17^{\text {th }}$ century ${ }^{3}$. At the time, one of the theories against Galen's views emerged, mainly based on those of Thomas Willis (1621-1675), the eminent theoretician, and Thomas Sydenham (1624-1689), the famous clinician. The proposed thesis was that the seat of hysteria would be the nervous system, where animal spirits were supposed to circulate $^{1}$. Sydenham reinforced the idea that hysteria was not a uterine disease, and could be seen as a frequent manifestation $^{3}$. Concepts of nervous disorders came into regular use in Britain, after Cheyne's book, "The English Malady" or a "Treatise of Nervous Diseases" (1733), was published. In France and Britain, these ideas provided the basis for a whole "nervous culture" in a self ascribed "refined, sensitive, and civilized society". Subsequently, William Cullen (1712-1790) coined the term "neurosis" or "nervous disease", which included several disorders, among them the "Spasmi" (as epilepsy, chorea, hysteria $)^{3}$. The 1800s brought an increase of theories about hysteria, including the "uterine neurosis", with the organ indirectly linked to the central nervous system, or the "encephalopathic" hysteria, primarily starting in the brain ${ }^{4}$. Later, Moritz Romberg (1840-1946) explained hysteria as a reflex neurosis caused by the irritation of the genital organs that could promote convulsions, paralysis, and the hysterical bolus ${ }^{2}$.

\section{SALPÊTRIÈRE HYSTERIA ERA}

The $19^{\text {th }}$ century gave rise to the French medical supremacy, with the study of hysteria in hospital setting, replacing the English one of the previous century. The French School detained the anatomical-clinical characterization of diseases, taking advantage of the rich experience acquired from the crowded Parisian hospitals.

Female patients with episodical behaviors, such as epileptics and hysterics, were gathered in the same building, in La Salpêtrière, what favored Jean-Martin Charcot (1825-1893) to develop his views about both disorders. However, hysteria continued to be a puzzle ready to unleash exhaustive studies led by Charcot, since his first insights on the theme, at the time he got his Service, until his death (1862-1893). As a precursor, Charcot had Pierre Briquet (1796-1881), who regarded hysteria as an encephalic neurosis caused by the action of a variety of unpleasant environmental events in the brain of susceptible and predisposed individuals ${ }^{4,5,6}$. Besides Briquet, other predecessors in the study of this disorder, in the second half of the $19^{\text {th }}$ century, such as Charles Laségue and Russell Reynolds, should be mentioned. Charcot's main scientific interest was devoted to describing and understanding the mechanisms of hysteria, emphasizing a hereditary predisposition, and the presence of a provocative agent, besides the influence of strong moral feelings and psychological trauma ${ }^{5,6,7}$. He also recognized a combination of organic and hysterical manifestations, and consequently brain pathologies could favor it ${ }^{6}$. Charcot's writings show an awareness of the relation between hysteria and emotional disorders, and a hereditary dynamic "physical lesion" confined in the brain, and precipitated by a trauma. Charcot would further boost his concept of hysteria as an organic brain disease due to a "functional" disorder of the cortex, as he was unable to find over there any microscopic abnormalities. He coined the term "dynamic lesions", a neurophysiologic alteration anatomically not discernible, which could produce a marked behavioral change ${ }^{6}$. Such belief, which could not be subjected to experimental evidence at his time, became apparent and possible with the advent of functional neuroimaging. Charcot emphasized also his discovery of "hysterogenic points", zones of hypersensitivity, which, when fingered, could provoke an attack, and that could be reversed by ovary compression ${ }^{5,6,7,8}$. Charcot created at the Salpêtrière (1890) a laboratory of clinical psychology. At this stage he believed that a nervous system lesion was responsible both for somatic and psychic hysteria components ${ }^{7}$. Charcot claimed to have isolated hysteria as a distinctive and universal disorder, and this assertion was partly based on the "grande attaque" . It must be acknowledged that Charcot performed his work in the Parisian Belle Époque, prone to artistic revolutions and theatricality. Charcot's understanding hysteria as a neurological disease attracted criticisms, as well as the methodology he used was not accurate enough, at the time, to unveil the basis of hysteria. Nevertheless, this model was the first one used by him. Later, he adapted his research strategies for the production of hysterical symptoms by introducing a psychological explanation, as he assumed that the patient had forgotten a particular body function. This involves a modern conception that an idea of a movement precedes it, and in the same way, it might be a sort of "paralysis depending on an idea", a Russell Reynolds's concept based on traumatic neurosis $(1869)^{6,7}$. Charcot understood that the paralysis was not imaginary (unreal), but due to the imagination (thoughts) ${ }^{7}$. Charcot accepted also hysteria in men, in the same way as Galen, Willis, Sydenham and Briquet, before him $^{5,6,7,8,9}$, and recognized that hysterical tremors were more common among them ${ }^{5}$. Paul Richer and Gilles de La Tourette were among Charcot's associates who most shared 


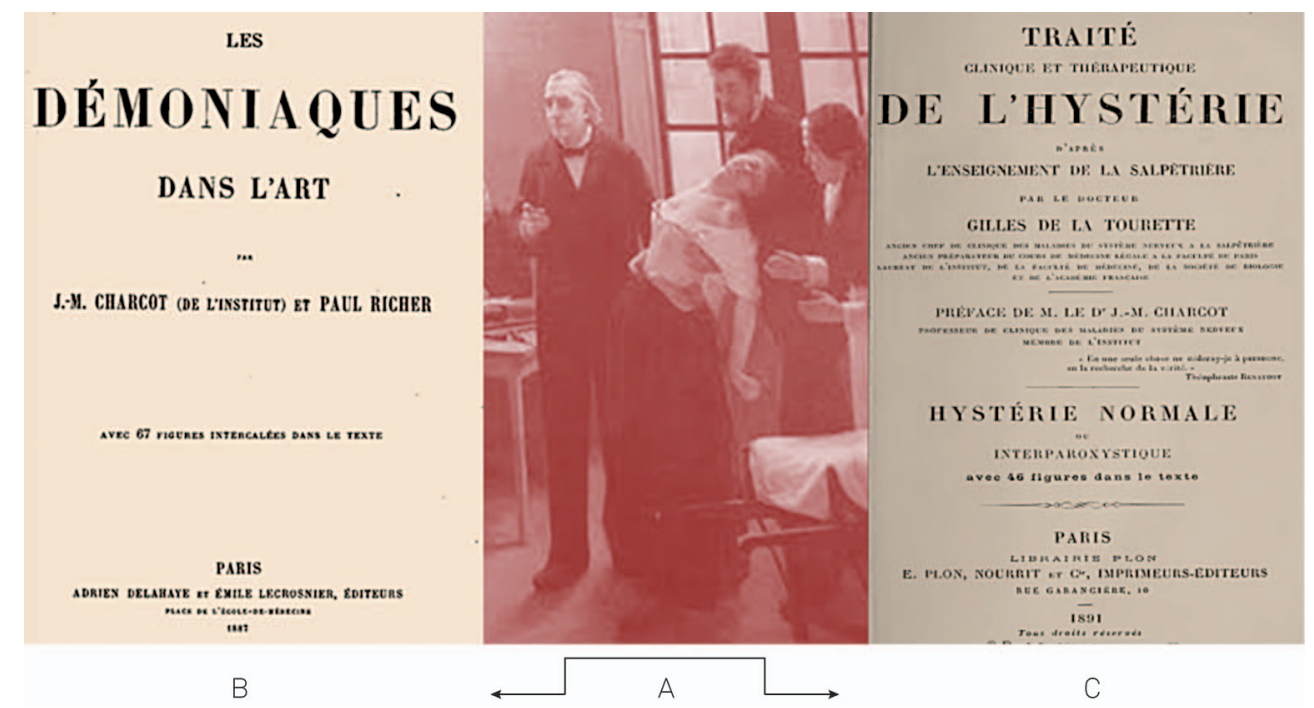

Figure 1. (A) The 1887 famous painting by André Brouillet (1857-1914) (a detail) shows in the first plain, Charcot and Babinski (Chacot's chefe de clinique - 1885-1887), besides Blanche Wittman (the woman fainting in Babinski's arms during Charcot's lecture) and Marguerite Bottard (Charcot's chief nurse) ${ }^{7}$. Charcot had as hysteria study's co-authors, besides his team (mainly Pitres, Richer, Gilles de la Tourette, Sollier, Babinski, and later, Janet), the active co-participation and collaboration of some patients. Babinski later denounced the theatrical and artificial spectacle that for him created a simulated Clinique ${ }^{7}$; (B) However, Paul Richer (Les démoniaques dans l'art )"; and (C) Gilles de la Tourette (Traité clinique et thérapeutique de l'hystérie d'après l'enseignement de la Salpêtrière $)^{5}$ were faithful allies of Charcot's ideas on hysteria.

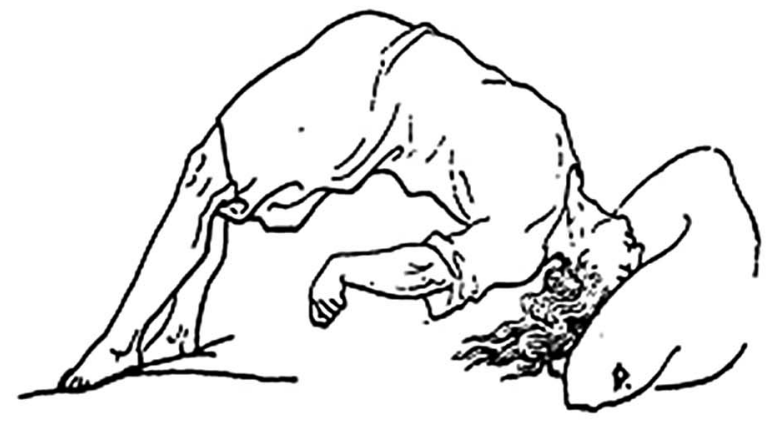

From Iconographie

Photographique de la Salpêtrière $2^{\text {nd }}$ stage, included the "arc-en-cercle"

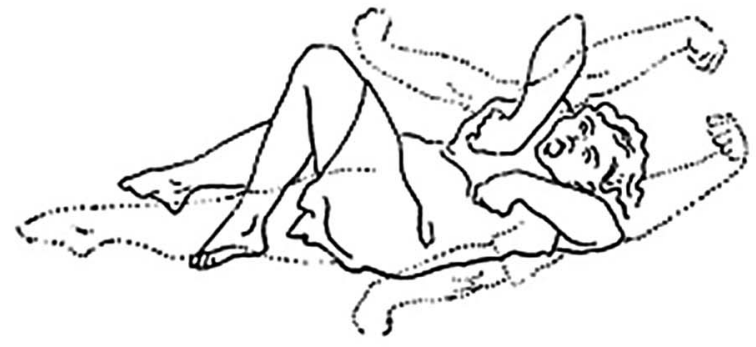

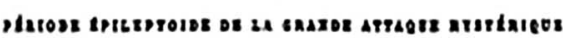

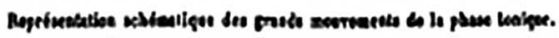

From Les Demoniaques dans L'Art

(1 ${ }^{\text {st }}$ stage, epileptic periode)

Figure 2. The persons with epilepsy offered a profusion of artistic material for the Salpêtrière studies on hysteria, as can be seen in two publications with Charcot's participation: the Iconographie Photographique de la Salpêtrière $(1877)^{10}$ and Les Demoniaques dans L'Art (1887) ${ }^{9}$. The Iconographie Photographique de la Salpêtrière was a key element in the Parisian Hysteria approach ${ }^{8,10}$. Charcot's disciples, mainly Bourneville, who arranged for the publication of Charcot's works, produced several of its volumes. In Les Demoniaques dans L'Art, Richer and Charcot pursuits all forms of works of art to exemplify the syndrome of hysteria and its various bodily expressions. The last chapter includes a detailed text description and pictorial representation of the four stages of hysteria of the great epileptic attack. The patients allegedly evolve through these stages, the second one includes the arc-encercle, the most well known": $1^{\text {st }}$ epileptic period (“... it is necessary to divide it into three phases: the tonic phase, the clonic phase, and the resolution phase"); $2^{\text {nd }}$ clownistic period ("It consists of two distinct orders of phenomena: the great contortions and movements by different processes meet the same principle dominant throughout this period and seeking the same result, that an overstated amount of muscle strength"); $3^{\text {rd }}$ passionate attitude period ("Hallucination obviously chairs this third period"); $4^{\text {th }}$ terminal period ("After a period of passionate attitudes or plastic poses, one might say, strictly speaking, the attack is over. Knowledge is back, but only in part, and for a while the patient remains in the grip of a delusion whose character varies; it is intersected by hallucinations and sometimes accompanied by some movement disorders"). 
Box 1. Synthesis of the neurological pathway of hysteria.

The "neurogenic hysteria way" traverses various theories: "mechanical" (in the ancient Egyptians 1900 BC Kahun Papyrus identifies the cause of hysterical disorders in spontaneous uterus movement within the female body); "sympathetic"; "uterinus neurosis"; "encephalopathic"; "reflex", until theory of hysteria as a "functional", disturbance of the cortex, and a neurogenic model of "the great neurosis". This last one was mainly effected by Charcot and his School, and is now reemerging with the neuroimaging innovations. More thoughts about this odyssey are unfolded. Several neuroimaging studies published in the literature aim to explore the objective neural correlates of functional mechanisms, which without structural brain lesion would be involved in conversion disorders. Other issues on this path of hysteria are given by the authors of this paper: on the importance of hysteria in Charcot's work (Jean-Martin Charcot, father of modern neurology: an homage 120 years after his death) and Joseph Babinski's approach to the somatoform disorders (Hysteria to conversion disorders: Babinski's Contributions), on previous papers published in this same Journal.

Box 2. Traité clinique et thérapeutique de l'hystérie d'après l'enseignement de la Salpêtrière (Clinical and therapeutic treatise on hysteria according the teaching of the Salpêtrière), by Gilles de la Tourette ${ }^{5}$.

This volume on hysteria, prefaced by Charcot, comprises 12 chapters, where the ideas were validated by him, in its virtues and weaknesses.

\section{PREFACE}

"The present Treatise was completed, in a certain way, under my direct supervision. It reproduces, as faithfully as possible, my teachings and the works it has inspired my pupils. I could say more: as I read the work of Gilles de la Tourette before it was printed, I was repeatedly surprised to find ideas that were absolutely personal to me, which I believe I have never expressed, and that, in any case, had remained novel. The reason is that Gilles de la Tourette, who was my interne and my chef de clinique at La Salpêtrière, after nearly eight years engaged in daily duty in my Service, collecting, inspired by clinical observation, my thoughts or sayings about hysteria, working without rest, was able to produce a work that, presently, I believe, comes to fulfill a gap in science...”J. M. Charcot Paris, 15 October 1891.

\section{TABLE OF CONTENTS}

$01^{\text {st }}$ Chap. Historical considerations

"It was in 1862 that our maitre took at Salpêtrière the Service he would make famous. In charge of the Section of hysterics, his first research turned mainly to the most common manifestation of hysteria, the convulsive attack. The description he found among the authors did not satisfy him; always searching, he perceived that this symptomatic complexity had its laws, and that the attack did not simply consists, brutally, by uncoordinated convulsions. In 1868 his clinical lectures begun, allowing him finally to give the true characteristics of the attack, establish its laws, and definitively determine the relations which bring together hysteria and epilepsy."

02 ${ }^{\text {nd }}$ Chap. Etiology.

$03^{\text {rd }}$ Chap. The provoking agents of hysteria.

$04^{\text {th }}$ Chap. Permanent hysterical stigmata. The cutaneous anaesthesia.

$05^{\text {th }}$ Chap. Anaesthesia of mucous membranes and sensory organs.

$06^{\text {th }}$ Chap. The hysterical hyperaesthesias and hysterogenic areas.

$07^{\text {th }}$ Chap. On some hysterogenic hyperesthesic areas in particular.

$08^{\text {th }}$ Chap. Hysterical disorders on the vision apparatus. On hysterical ambliopia.

09 $9^{\text {th }}$ Chap. Hysterical affections of the eye muscles.

$10^{\text {th }}$ Chap. Diathesis of contracture; amyosthenia; hysterical tremor.

$11^{\text {th }}$ Chap. On the mental state of hysterics.

$12^{\text {th }}$ Chap. Nutrition in the normal hysteria.

his ideas, as can be seen from the published works on this subject (Figures 1 and 2, Box 1 and 2). Finally, it is remarkable that Charcot's neurogenic conception on hysteria reap- peared, conducting to a psychobiological model of this condition founded on varied types of neuroimaging studies.

\section{References}

1. Merskey H, Merskey SJ. Hysteria, or "suffocation of the mother". CMAJ. 1993;148(3):399-405.

2. Bonomi $\mathrm{C}$. The relevance of castration and circumcision to the origins of psychoanalysis: 1. The medical context. Int J Psychoanal. 2009;90(3):551-80. http://dx.doi.org/10.1111/j.1745-8315.2009.00134.x

3. Hare E. The history of 'nervous disorders' from 1600 to 1840, and a comparison with modern views. Br J Psychiatry. 1991;159(1):37-45. http://dx.doi.org/10.1192/bjp.159.1.37

4. Fontoura P. The 'Ajuda Paralyses': history of a neuropsychiatric debate in mid-19th-century Portugal. Brain. 2010;133(10):3141-52. http://dx.doi.org/10.1093/brain/awq211

5. Gilles de la Tourette G. Traité clinique et thérapeutique de l'hystérie d'après l'enseignement de la Salpêtrière. Paris: Plon Nourrit; 1891.
6. White MB. Jean-Martin Charcot's contributions to the interface between neurology and psychiatry. Can $J$ Neurol Sci. 1997;24(3):254-60.

7. Allilaire JF. [Babinski and hysteria]. Bull Acad Natl Med. 2007;191(7):1329-39. French.

8. Faber DP. Jean-Martin Charcot and the epilepsy/hysteria relationship. J Hist Neurosci. 1997;6(3):275-290. http://dx.doi.org/10.1080/ 09647049709525714

9. Charcot JM, Richer PMLP. Les démoniaques dans l'art. Paris: Delahaye et Lecrosnier; 1887.

10. Bourneville DM, Regnard P. Iconographie photographique de la Salpêtrière. Paris: Progrès Medical; 1877. 